\title{
BUCHBESPRECHUNGEN
}

\author{
GeRHARd LeIBHOlZ (Herausg.)
}

Jahrbuch des öffentlichen Rechts der Gegenwart

Neue Folge, Bd. 23 (1974), DM 169,-; Bd. 24 (1975), DM 215,-; Bd. 25 (1976), DM 220,-; Bd. 26 (1977), DM 249,-; Register zu Band 1 bis 25 (1978), DM 144,--

J. C. B. Mohr (Paul Siebeck), Tübingen

The Jahrbuch des öffentlichen Rechts was edited between 1907 and 1937 in 24 volumes, and since 195126 volumes have been published in the "New Series". The editor is Professor Dr. Gerhard Leibholz, formerly a judge at the Bundesverfassungsgericht. The Jahrbuch publishes articles and occasionally some documentary material but no book reviews or decisions of courts. It is a forum also for foreign authors (the four volumes under review here contain 38 contributions by foreign authors and 30 articles by German authors; less than two thirds of the contributions are in German, the remainder are written mostly in English and some of them in French). The following survey of the last four volumes of the Jahrbuch includes all articles on matters also belonging to the domain of Verfassung und Recht in Ubersee; furthermore, some articles are included which might be of particular interest to readers overseas.

The Jahrbuch distinguishes between the development of constitutional law in the "European area" and in the "non-European area", the latter being subdivided into the mediterranean area, the North American, Asian and African areas.

a) "European Constitutional Law". For the Jahrbuch, this term comprises the law of the European Communities. This is in accordance with a terminology which tries to go beyond terms as "supra-national law", "integrative law", or "federative law", thereby implying a political statement: it is certainly not a mere coincidence that pronounced supporters of a stronger European integration should choose the term European ,,constitution" "1. In the last issues of the Jahrbuch problems of community law and of British Constitutional law resulting from the United Kingdom's access to the European Community in 1972 occupy considerable space. Walter (vol. 24) reports on judgements of the European Court for Human Rights between 1959 and 1974 focussing on Articles 5 an 6 (this is certainly not a contribution to the "European Constitutional Law" as defined above, for the member states of the European Convention on Human Rights do not form a constitutional community).

b) Constitutional Law in European Countries. The principal aim of the Jahrbuch is to follow up the development of the Constitutional law in the individual European States. This is done most of the time in the form of a report on the situation of individual countries in a particular period. From the socialist countries, Poland (1958-1974, Zakrzewski, vol. 24), Romania (1965-1975, Cismarescu, vol. 24), Hungary (1949-1972, Antalffy, vol. 24), and Jugoslavia (1968-1977, Kulic, vol. 26) are represented.

Whereas some parts of the article on Hungary and Jugoslavia read like official commentaries, Zakrezewski's contribution contains also analytical passages, although the role of the Polish Labour Party in the constitutional reality is nowhere elaborated upon - a role which, it is true, is not described in the text of the constitution.

\footnotetext{
1 Judge Pescatore of the European Court, for example, qualified in a lecture given at the university of Zurich any other term as "useless", cf. Neue Zürcher Zeitung, 5th May of 1978.
} 
Among the reports on Western states are reports on Austria (Ermacora, vol. 24 and 26, who devotes much space to Austria's home and foreign policies), a report by Beck on the development in Spain between 1972 and 1977 (vol. 26) with emphasis on reforms and reform plans after Franco's death, and an article on the Swedish Constitution of 1975 (Stjernquist, vol. 26).

Of particular interest is Wildhaber's contribution on Switzerland (vol. 26). The author is chairman of the Commission of experts in charge of preparing a complete revision of the Federal Constitution; the Commission submitted its report in February 1978, thereby bringing to an end a discussion which had lasted for more than 12 years. Wildhaber offers first-hand information on the Commission's ideas on basic rights, fundamental principles of state action, the social and economic system, the relation between the federal authority and the cantons, and he discusses these matters in the context of the debate of lex lata and lex ferenda. It becomes evident that with regard to the economic order the Commission have tried to find norms that are in accordance with developments of the past years, especially with the judicature of the Bundesgericht. Viewed against this background, the criticism that has been raised in some sections of the Swiss public against the draft, in particular its "progressism" and "remoteness" from what the Swiss people want, is difficult to understand for the foreign observer.

Apart from these reports on individual countries, the Jahrbuch contains articles on particular problems, especially on matters relating to federalism and parlamentarism. In vol. 25 Morscher enters upon a comparative investigation of parliamentary interpellation, which, however, remains a compilation of materials, because the author does not procede to evaluate the different ways of interpellation against the background of other mechanism of parliamentary control.

c) America. Contributions on the United States have always occupied a large space in the Jahrbuch: there are nine articles in four volumes. Kommers and Gallagher (vol. 25) report in great detail upon the development of „,Government and Politics“ and upon „Civil Rights and Liberties between 1964 and 1976". The contributions are particularly fruitful as far as the problems of judicial control of political decisions are concerned: Rendel deals with the matter in an essay (vol. 24), the center of interest being a comparison with the French Conseil d'Etat; the studies of Petersmann and Zeitler (both in vol. 25) on the judicial control of external powers are instructive. Some remarks on the role of the Argentinian Supreme Court under the different military regimes between 1930 and 1973 (Snow, vol. 24) are the only contribution in the section on America not relating to the United States or Canada.

d) The Third World. Non-European countries bordering on the Mediterranean are represented in a number of reports. The French author Camau (vol. 23 and 24) describes the development of Algerian constitutional law in the country's first ten years of independence (vol. 23). He clearly shows the particuliarities of the system and the role of the Front de Libération Nationale whose functions are laid down in the Constitution. In vol. 24 the same author deals with the constitutional development in Tunisia between 1970 and 1975, the interesting period between the elimination of the "Socialists" centering around Ben Salah and Bourgiba's election to lifelong presidency. The Turkish development between 1961 and 1974 is dealt with by Hirsch (vol. 23), who was professor at several Turkish universities from 1933 until after the war. He explains the alterations introduced into the text of the Turkish Constitution of 1961, thereby excluding the legislation of the Turkish Constitutional Court as well as the Turkish and non-Turkish literature on the subject - the latter on the grounds of its being ,frequently politically biased“" (p. 337)! Hirsch is here referring to the criticism raised against the period of indirect military government between 1971 and 1973, resp. the altera- 
tion of the Constitution in $1971 .^{2}$ His basically positive attitude towards the conservative elites of Turkey, as it is revealed in this remark, can also be sensed in the analytical passages of the article. Klinghoffer (vol. 24) discusses problems of the boundaries of Israel and the delicate ,,Who-is-a- Jew -question“, which he deals with on the basis of court decisions in individual cases. The most recent and comprehensive monograph on the subject could not be taken into account at the time of publication. ${ }^{3}$

Each of the four volumes of the Jahrbuch contains a contribution by Kapur, all of which reveal an extraordinary familiarity with the subject and are distinguished by their presentation in terms of cases only. In vol. 23 Kapur presents the 1950 Constitution and its alterations; the other contributions start out from actual controversies and deal with the Supreme Court's competence in matters of election-law (vol. 24), the emergency powers of the President (vol. 25 , on the occasion of Indira Ghandi's declaration of the state of emergency on June 25, $1975^{4}$ ), and the power of the President to dissolve provincial parliaments (vol. 26).

Kwon's treatment of the South Korean Constitution of 1972 (vol. 24) represents a unique case. On the one hand, the discussion remains purely normative and disregards the historical setting: no mention whatsoever is made of President Park's policy, who, in 1962, broke the constitution, prolonged the State of emergency, dissolved Parliament and then set up a Constitution granting nearly unlimited rights to the President. In the footnotes, however, and very occasionally in the text itself, Kwon puts the new Korean Constitution to the test of the doctrines of German constitutional lawyers. This sometimes leads to absurd statements, as for example when Kwon tries to make immediate use of comments by Jellinek, Bettermann and Hesse on the Bonn Grundgesetz of 1949 for the interpretation of the Korean Constitution: categories such as Grundrecht, Sittengesetz, Rechtsstaat, Gesetzesvorbehalt are treated as if they existed a priori and as if they were common to all constitutional systems. It is nevertheless worth noting that by doing so, Kwon adds to his presentation a critical dimension which one would not expect to find when reading only the text of his article.

The Japanese constitutional development between 1965 and 1976 is presented by Abe and Shiyaka (vol. 26). The article refers to a number of court decisions and also contains statistical data (especially on political parties, elections, and judges). The contribution is of special interest to the German reader because it shows how comparable societies give rise to similar judicial problems: as in the Federal Republic the strike by civil servants is a matter of heavy controversy in Japan (some courts having deemed the strike permissible, it was declared inadmissable by the Supreme Court in 1973). In both countries there is a discussion of an individual right to an unpolluted environment. It is also remarkable that in spite of the freedom of opinion and that of speech and writing being comprehensively guaranteed in the Constitution (Art. 19, 21) and in spite of the right to demonstration being unanimously confirmed case law, the Supreme court should have recognized the participation in a demonstration against the Government as a cause for dismissal from work. Abe and Shiyaka, who praise Japan as being "one of the freest countries of the world" (p. 596), confirm this (cf. p. $613 \mathrm{f}$.). Further contributions on Japan, both of them rather short, deal with the Supreme court (Wada, vol. 23) and local administration (Sato, vol. 25).

Sub-Saharan Africa is the subject of only three articles. The American Rubin (vol. 25) reports on the development in Ghana after the overthrow of the Nkrumah regime, praising the only fifteen-month long government of the Christian Professor of Sociology, Busia, under which Ghana, according to the author, had been a "democratic oasis" (p. 489). This thesis ignores

2 Cf. Hirsch, VRU 5 (1972), p. 195, and the controversy between Tibi, VRU 5 (1972), p. 447, and Rabl, VRU 6 (1973), p. 219.

3 Kraines, The Impossible Dilemma: Who is a Jew in the State of Israel?, 1976.

4 Cf. Noorani, VRU 11 (1978), p. 403. 
that Busia was the representative of a small, regionally and economically definable minority, and that the period of his government is to be regarded rather as an illustration of how the transfer of Western democratic mechanisms into countries of the Third World does not honour the claim which it is generally coupled with ${ }^{5}$. Scholler's detailed study on Ethiopia after the overthrow of the emperor (vol. 25) contains interesting remarks on the "derg" committee panel which combined executive and legislative competences and for some time even functioned as Head of State.

A contribution such as the one by the two Austrians Hummer and Hinterleitner (vol. 26) on supraregional, regional and subregional cooperation and integration on the African continent one would not expect to find in the Jahrbuch because of its orientation concerning foreign policy. The article is chiefly of documentary value.

This survey should have made clear that the Jahrbuch is not a manual on the development of "public law" in the world but a collection of articles on constitutional law with focus on Europe and North America. The methodological critique raised against earlier volumes in this journal ${ }^{6}$ can be upheld only in a few cases as regards the volumes under discussion here: some of the articles (especially those on Socialist constitutions) contain little more than some information on written norms and do not clarify the historical and political context.

It is to be hoped that the Jahrbuch will abandon the practice of having a single author deal with one country (For example, letting the retired Judge of the Supreme Court, of India, Kapur, advance his views in each of these four volumes - as well as in the preceding volumes 11 and 14).

Finally: it is noticeable that the Jahrbuch repeatedly gives contributors (especially German ones) the opportunity to deal with matters on which they have previously published monographies, mostly doctoral dissertations. This is the case approxiamately ten times here, more puzzling, it is true, to the German reader than to the reader abroad, who of ten does not have access to the original works. -

The "Register zu Band 1-25" contains lists of authors and titles of contributions as well as a detailed alphabetical subject index (in German). The most reliable way to find a particular topic appears to be to look under the respective name of the country: for example, "head of state" is listed under "Spain", but "Spain" is not entered under "head of state" (where on the other hand "France", "Tanzania" and others are registered). Most probably the Register will serve as a very useful guide in surveying the many articles published in the Jahrbuch between 1951 and 1976.

Philip Kunig

Robert J. Akxerman, Peter J. van Krieken, Charles O. Pannenborg (Herausg.)

\section{Declarations on Principles}

A Quest for Universal Peace

Liber Amicorum Discipulorumque Prof. Dr. Bert V. A. Röling

A. W. Sijthoff,

Leyden, 1977.

Der Niederländer Röling war Strafrechtler, Kriminologe, Richter, Mitglied des Tokioter Kriegsverbrechertribunals, außenpolitischer Berater niederländischer Regierungen, seit 1950 zugleich auch Professor des internationalen Rechts; 1961 gründete er ein Institut für

5 See Tetzlaff, in Ansprenger/Traeder/Tetzlaff (eds.), Die politische Entwicklung Ghanas von Nkrumah bis Busia, 1972 , p. 127 et seq. 229; Opoku, VRU 5 (1972), p. 470.

6 Cf. von Wedel, VRU 6 (1973), p. 251, 7 (1974), p. 357, and Krakau, VRU 6 (1973), p. 500. 